Article

\title{
An Open Innovation Intraday Implied Volatility for Pricing Australian Dollar Options
}

\author{
Thi Le $(\mathbb{B}$, Ariful Hoque *(1) and Kamrul Hassan \\ Murdoch Business School, Murdoch University, Perth 6150, Australia; thi.le@murdoch.edu.au (T.L.); \\ k.hassan@murdoch.edu.au (K.H.) \\ * Correspondence: a.hoque@murdoch.edu.au
}

Citation: Le, T.; Hoque, A.; Hassan,

K. An Open Innovation Intraday

Implied Volatility for Pricing

Australian Dollar Options. J. Open

Innov. Technol. Mark. Complex. 2021, 7,

23. https://doi.org/10.3390/

joitmc7010023

Received: 10 December 2020

Accepted: 5 January 2021

Published: 9 January 2021

Publisher's Note: MDPI stays neutral with regard to jurisdictional clai$\mathrm{ms}$ in published maps and institutional affiliations.

Copyright: (C) 2021 by the authors. Licensee MDPI, Basel, Switzerland. This article is an open access article distributed under the terms and conditions of the Creative Commons Attribution (CC BY) license (https:// creativecommons.org/licenses/by/ $4.0 /)$.

\begin{abstract}
This study introduces the intraday implied volatility (IV) for pricing the Australian dollar (AUD) options. The IV is estimated using the at-the-money one-month, two-month, and threemonth maturity AUD options traded in the opening, midday, and closing period of a trading day. The Mincer-Zarnowitz regression test evaluates the predictive power of IV to forecast the foreign exchange volatility for the within-week, one-week, and one-month horizon. The mean absolute error, mean squared error, and root mean squared error measures are employed to assess the performance of IV in estimating the price of currency options for the within-week, one-week, and one-month horizon. This study reveals four critical findings. First, a three-month maturity IV does not contain vital information for pricing options. Second, IV incorporated information is not relevant to compute the value of options for a horizon of less than a week. Third, IV in the closing period of Monday or Tuesday subsumes most of the essential information to estimate options price. Fourth, the shorter (longer) maturity IV provides critical information to price options for the shorter (longer) horizon. The intraday IV is a new dimension of unobservable volatility in accurately pricing currency options for researchers and practitioners.
\end{abstract}

Keywords: intraday implied volatility; realised volatility; Australian dollar options; Mincer-Zarnowitz regression

\section{Introduction}

This study introduces intraday implied volatility (IV) which is an innovative approach to estimate the volatility of underlying currency for pricing currency options accurately. The intraday IV captures the market information at the opening, midday, and closing period of a trading day for pricing options with higher accuracy. If the options are mispriced, particularly overpriced options, it will increase the cost for hedging using currency options. The 2019 Bank for International Settlement (BIS) Triennial Survey results reveal that the turnover in Australian dollar (AUD) options increased by 58 percent between April 2016 and April 2019 [1], which is significant compared to other currency options. Therefore, Australian dollar options are considered to assess the capability of intraday IV to holding appropriate market information for pricing options precisely.

Foreign exchange (FX) risks are reported as one of the major risks related to foreign investments and international assets pricing [2]. Most portfolio managers have been using FX options as their primary hedging tools to manage these risks [3]. The flexibility of currency options in creating a customised risk/return profile to achieve a specific investment objective has led to the significant growth of the FX options market. Holding currency options for various investment decisions such as hedging or speculation can be costly if the options are mispriced. Options mispricing affects the selection of hedge ratio, hedging efficiency, as well as expected hedging costs [4]. For this reason, the accuracy of currency options pricing has been attracting the attention of market participants [5]. Currently, the most commonly used model to calculate European options prices is known as the Black-Scholes [6] (BS) 
model [7]. The BS model assumes constant volatility. If true, this assumption would lead to a flat implied volatility curve. Observed implied volatility in practice differs across option contracts, depending on both moneyness and time to maturity. However, due to the theoretical approximation between the stochastic volatility and conditional volatility models to BS for at-the-money (ATM) options and nearest to expiration [8,9] and the rich informational content, implied volatility is still of interest [10-13] and the BS model is still widely applied [14]. Using the Merton [15] version of the BS model (BSM) to calculate prices of European currency options, all components are observable except the volatility of the underlying currency. Errors in the estimation of volatility result in the options mispricing [16-18]. The improvement of volatility estimation leads to lower errors of option prices [19]. Hence, forecasts of future volatility of underlying assets are vital for estimating and forecasting the currency options price accurately.

The literature has explored the volatility intensively. As the options prices reflect the market's expectation about the future movements of the prices of the underlying asset over the remaining life of the option contract, more research concentrates on volatility implied in options prices [20]. The implied volatility (IV) contains all available information, including historical data [10,20-25]. It is widely accepted that the IV from the market options price is a reasonable measure of the market's opinion of the volatility of the underlying asset. The forward-looking IV subsumes relevant information in terms of future volatility, and it often outperforms historical volatility in predicting future realised volatility $(R V)$. Such superior performance was recognised in different types of assets [26]. For currency options, the majority of both previous and more current research found that IV was a reliable predictor of future volatility. IV contained valuable information for volatility forecasting and captured approximately 50 per cent of actual currency volatility [27].

However, most of the previous research used the conventional approach that was based on daily IV obtained from daily closing options prices. As the operation of financial markets during their opening trading hour are based on a continuous, high-frequency basis, the conventional method using a discrete sample of datasets on markets at a significantly lower frequency with the majority of data being extracted per day, or per week to forecast volatility is no longer relevant [28]. New technologies have been creating opportunities to obtain better, faster, and more efficient datasets to explore financial market phenomena at the finest levels of data [29]. It provides reliable intraday data to supporting financial investment decisions across different assets classes and instruments consisting of commodities, derivatives, equities, fixed income, and foreign exchange [30]. The purpose of this paper is to investigate the performance of the intraday implied volatility (IV) for pricing the Australian dollar (AUD) options. This study has three major contributions.

First, this study introduces an intraday IV approach based on the one-month, twomonth, and three-month maturity options traded in the opening, midday, and closing period of a trading day, which captures the most relevant information of the FX in estimating options prices. Second, the research findings indicate that the one-month and two-month maturity intraday IV holds vital information to predict the volatility of the underlying currency of options for the one-week and one-month forecast horizon, respectively. Third, this research confirms that the information content embedded in the IV based on the one-month and two-month maturity options is appropriate to estimate the value of currency options for the one-week and one-month horizon, respectively.

The rest of the paper proceeds as follows. Section 2 discusses the literature review. The next section describes the methodology and data used in this study. Section 4 conducts the empirical analysis, followed by the discussion of the findings. The last section concludes the paper.

\section{Literature Review}

$\mathrm{Xu}$ and Taylor [31] examined the informational efficiency of the four currency options (British pound (GBP), Deutsche mark (DEM), Japanese yen (JPY), and Swiss franc (CHF) against the US dollar (USD)) from January 1985 to January 1992 and concluded that 
option prices subsumed useful information about future volatilities. Likewise, Jorion [32] tested the predictive power of DEM, JPY, and CHF against the USD and found that IV contained more information content compared to statistical time-series models. Kazantzis and Tessaromatis [33] analysed the information content and predictive power of IV using six currency options (JPY, DEM, GBP, CHF, Canadian dollar (CAD), and AUD against the USD) from December 1989 to April 1997. The findings indicated that IV was more informative than historical and GARCH-based volatilities for horizons ranging from one day to three months. Kim and Kim [34] showed that the IV of the CAD, CHF, DEM, GBP, and JPY options tended to be low in the early part of the week but remain high in the last part of the week beginning on Wednesdays. Chang and Tabak [35] produced evidence that the IV of Brazilian options contained vital information that was missing in the econometric models and it provided superior foreign exchange (FX) forecasts. Busch et al. [23] explored the role of IV in predicting future volatility and found that IV was an unbiased predictor and provided helpful information for volatility forecasting in the FX market. Pilbeam and Langeland [36] recognised that the IV of CHF, EUR, GBP, and JPY provided a superior performance compared to the GARCH model in both the low and high volatility periods of the FX market. Sahoo and Trivedi [37] showed that IV outperformed historical volatilities in forecasting future $R V$. Wong and Heaney [38] found the knowledge of the volatility smile, which were implied from the one-month maturity of GBP/USD, EUR/USD, AUD/USD, and USD/JPY options, improved FX volatility forecast accuracy. Covrig and Low [39] used over-the-counter (OTC) data for USD per GBP, JPY per USD, and USD per AUD to examine the information of IV for different forecast horizons. They suggested that quoted IV subsumed the information content of historically based forecasts at shorter horizons (one-month and two-month horizon). Pong et al. [40] found that the IV of the DEM, GBP, and JPY options incorporated most of the relevant information for the forecast horizon of either one-month or three-month. Christoffersen and Mazzotta [41] revealed that the IV of at-the-money (ATM) options for the EUR, GBP, and JPY mostly provided the unbiased and reasonably accurate forecasts of actual volatility one month and three months out.

Until the late 1970s, using monthly data played an essential role in empirical research due to the unavailability of and access problems to higher frequency data, such as daily or intraday data. However, the development of information technology in the 1990s provided access to time-stamped observations on all quotes and transactions. These tick-by-tick data, termed as ultra-high-frequency data by Engle [42], are usually referred to as highfrequency data in current studies. High-frequency data indicated that many financial assets experienced the particular intraday patterns [20] and these patterns were significantly associated with intraday returns variations, volatility, volume, and bid-ask spreads [43]. A large number of studies suggested that intraday trading activities exhibited a U-shaped pattern with the trading volumes being extremely high at the market's opening and closing periods, such as Wood et al. [44], Gerety and Mulherin [45], Brock and Kleidon [46] for the New York Stock Exchange (NYSE); Mclnish and Wood [47] for the Toronto Stock Exchange; and Hamao and Hasbrouck [48] for the Tokyo stock exchange. Several studies reported the M-shaped [29,49] or J-shaped patterns [50] for the UK stock exchange. Most of the research found the importance of intraday data in improving volatility predicting. There was a significant amount of information in the five-minute returns when estimating hourly variances [51-53]. Wang and Wang [20] explored the capability of intraday IV information content using the S\&P500 Index as a sample from 2005 to 2010. Their study recognised that the IV around noon contains more useful information regarding future volatility than IV at the market's closing period, which has been frequently used in the previous literature. Trading at a specific time of the trading day is motivated by specific information and risk factors, which do not remain during other times. Hence, our paper investigates the performance of IV in estimating and forecasting options prices at three different trading time periods of the trading day (opening, midday, and closing) using the AUD currency options datasets covering the period from 2010 to 2017. 
Previous studies focused on the daily IV of currency options to forecast the volatility of FX. There are not many pieces of research utilising the high-frequency data and intraday IV in estimating and forecasting volatility. Furthermore, IV incorporated information has not been used for pricing options. Therefore, this paper will examine the capability of intraday IV with different time to maturity in forecasting future volatility and estimating currency options price.

\section{Materials and Methods}

\subsection{Data Description}

This study used AUD currency options provided by the Options Price Reporting Authority (OPRA) as the last-sale options quotations. We obtained data from Thomson Reuters' database through the Securities Industry Research Centre of Asia-Pacific (SIRCA). The sample period began on 01 January 2010 and ended on 31 December 2017. The options were traded on Monday to Friday, excluding public holidays from 9:30 to 16:00 (US Eastern standard time), and expired on the third Friday of each month. The options were European style, with the contract size of sample currency options being AUD 10,000 and settled in USD. The time to maturity of an option was assumed to be the number of calendar days remaining until the option matured. The sample options expired in one-month (2 to 30 days), two-month (31 to 60 days), and three-month (61 to 90 days) periods. The IV was calculated for the opening-period (9:30 to 10:00), midday-period (12:30 to 13:00), and closing-period (15:30 to 16:00) of a trading day. The time difference between "openingperiod" and "midday-period" and between "midday period" and "closing period" was equal (two and half hours) enough to position them evenly in a trading day. The BSM model assumed the volatility as constant, which introduced a bias into the IV estimation. Hull and White [54] stated that the magnitude of the bias in the BS model was the smallest for near-the-money options. Therefore, the IV was calculated based on the ATM one-month, two-month, and three-month maturity options traded during the opening, midday, and closing periods of a trading day.

We followed the ATM criteria in Xing et al. [55]; the ratio of the strike price to the stock price was considered between 0.95 and 1.05. The average of the close bid/ask quote of each five-minute interval was computed for each options price to mitigate problems due to bid/ask bounce [56]. The one-month, two-month, and three-month AUD and USD deposit interest rate were used as the proxy of the risk-free interest rate.

\subsection{Methodology}

The research methodology consists of five sub-sections, (i) calculating IV, (ii) computing realised volatility $(R V)$, (iii) IV forecasting $R V$, (iv) IV estimating options model price, and (v) estimating the options pricing error.

\subsubsection{Implied Volatility Calculation}

The BSM model replaces the stock price with foreign currency and considers the interest gained on holding foreign currency to be equivalent to a continuously paid stock dividend. The notation of the BSM model and its descriptions are as follows:

$C_{t}=$ price of call in domestic currency at time $\mathrm{t}$

$P_{t}=$ price of put in domestic currency at time $\mathrm{t}$

$S_{t}=$ spot price at time $\mathrm{t}$

$X_{t}=$ exercise price in domestic currency at time $\mathrm{t}$

$R_{t}^{d}=$ interest rate of domestic currency at time $\mathrm{t}$

$R_{t}^{f}=$ foreign currency interest rate at time $t$

$T=$ options expiration time

$\sigma_{t}=$ volatility of underlying currency

$N$ = cumulative normal distribution function 
In the BSM model, the European type call and put options are priced as:

$$
\begin{gathered}
C_{t}=S_{t} e^{-R_{t}^{f} T} N\left(d_{1, t}\right)-X_{t} e^{-R_{t}^{d}} N\left(d_{2, t}\right) \\
P_{t}=X_{t} e^{-R_{t}^{d} T} N\left(-d_{2, t}\right)-S_{t} e^{-R_{t}^{f}} N\left(-d_{1, t}\right)
\end{gathered}
$$

where,

$$
d_{1, t}=\frac{\ln \left(\frac{S_{t}}{X_{t}}\right)+\left(R_{t}^{d}-R_{t}^{f}+\frac{\sigma_{t}^{2}}{2}\right) T}{\sigma_{t} \sqrt{T}}
$$

And

$$
d_{2, t}=\frac{\ln \left(\frac{S_{t}}{X_{t}}\right)+\left(R_{t}^{d}-R_{t}^{f}-\frac{\sigma_{t}^{2}}{2}\right) T}{\sigma_{t} \sqrt{T}}=d_{1, t}-\sigma_{t} \sqrt{T}
$$

For notation convenience, let $\xi_{t}=e^{-R_{t}^{f} T}$ and $\eta_{t}=e^{-R_{t}^{d} T}$ so that Equations (1) and (2) can be written as follows:

$$
\begin{gathered}
C_{t}^{m k t, k, l}=S_{t} \xi_{t} N\left[d_{1, t}\left(\sigma_{c, t}^{k, l}\right)\right]-X_{t} \eta_{t} N\left[d_{2, t}\left(\sigma_{c, t}^{k, l}\right)\right] \\
P_{t}^{m k t, k, l}=X_{t} \eta_{t} N\left[-d_{2, t}\left(\sigma_{p, t}^{k, l}\right)\right]-S_{t} \xi_{t} N\left[-d_{1, t}\left(\sigma_{p, t}^{k, l}\right)\right]
\end{gathered}
$$

where $\forall_{m k t}=$ call and put market price; $\forall_{k}=$ one-month, two-month, three-month maturity options; $\forall_{l}=$ opening period, midday period, closing period. Now we calculate the implied volatility $\left(\sigma_{c, t}^{k, l}\right)$ for the ATM call options market price $\left(C_{t}^{m k t, k, l}\right)$ and implied volatility $\left(\sigma_{p, t}^{k, l}\right)$ for the ATM put options market price $\left(P_{t}^{m k t, k, l}\right)$ through the Newton-Raphson [57] iterative search procedure.

Despite the numerous suggestions about weighted-average techniques for calculating IV, there is no theoretically appropriate weighting scheme in the literature to estimate IV. We used the method suggested by Jorion [32] that computes IV as the average of the call options price IV and the put options' price IV. This study estimates IV as:

$$
\hat{\boldsymbol{\sigma}}_{t}^{k, l}=\frac{\hat{\boldsymbol{\sigma}}_{c, t}^{k, l}+\hat{\boldsymbol{\sigma}}_{p, t}^{k, l}}{2}
$$

\subsubsection{Realised Volatility Calculation}

The actual market volatility is unobservable, so in evaluating volatility estimating and forecasting, the usual proxy for "true volatility" is the so-called realised volatility $(R V)$. The $R V$ sums the squared intraday returns sampled at a particular rate of recurrence $[52,58]$. The optimal interval to construct the $R V$ is not known. Based on standard practice and previous literature, there is evidence that the five-minute $R V$ as the benchmark outperformed other measures, and it is difficult to significantly surpass the five-minute ( $5 \mathrm{~min}$ ) data frequency for $R V$ [53]. Consequently, this study used daily $R V$ series constructed from five-minute intraday spot prices as a proxy for the unobservable variance. If $S_{i}$ is the spot rate for a five-minute sampling frequency, the underlying exchange rate return in a five-minute interval was estimated as:

$$
r_{i, t}=\ln \left(\frac{S_{i}}{S_{i-1}}\right)
$$

where $r_{i, t}$ represents the return in interval $i$ on day $t$. Equation (7) computed the realised variance of day $t$,

$$
v_{t}=\sum_{i=1}^{n} r_{t, i}^{2}
$$


where $n$ denotes the total number of data points from 9:30 to 16:00 for Monday to Friday. Further, the $R V$ is the standard deviation of the realised variance. Therefore, the $R V$ per trading day is calculated as:

$$
\hat{\boldsymbol{\sigma}}_{t}^{R V}=\sqrt{v_{t}},
$$

As intraday data of trading days estimate the $R V$, when the exchange is closed, days are ignored and the $R V$ per annum is:

$$
\hat{\boldsymbol{\sigma}}_{t}^{R V}=\sqrt{D v_{t}},
$$

where $D$ is considered 252 trading days per year consistent with the normal assumption of the options market.

\subsubsection{Implied Volatility Forecasting Realised Volatility}

For IV from different maturities of options, the forecasting evaluation was implemented using the regression test introduced by Mincer and Zarnowitz [59], known as the Mincer-Zarnowitz (MZ) regression. In the MZ regression analysis, the $R V$ is regressed on a constant and IV as in Equation (12):

$$
\hat{\sigma}_{t}^{R V}=\beta_{0}+\beta_{1} \hat{\sigma}_{t-j}^{k, l}+\varepsilon_{t},
$$

where $\forall_{j}=$ within-week, one-week, and one-month horizon. The within-week horizon indicates that the IV is calculated one to four days before the date of $R V$ is computed. Similarly, the one-week and one-month horizon imply that the IV is estimated one week and one month before the date of $R V$ is obtained. The $\mathrm{MZ}$ regression allowed the evaluation of two different aspects to predict the volatility. First, the unbiasedness and efficiency of the forecast were evaluated by testing the intercept and slope through the joint hypothesis $\left(\mathrm{H}_{0}: \beta_{0}=0\right.$ and $\left.\beta_{1}=1\right)$ [60]. Second, the accuracy of the forecast was evaluated by the high goodness of fit value, $R$-squared $\left(R^{2}\right)$. The $R^{2}$ is a statistical measure that represents the percentage of the variance for $R V$ explained by IV. The value of $\mathrm{R}^{2}$ compares the predictive power of IV to forecast $R V$ for different horizons; such as, the $\mathrm{R}^{2}$ of IV for the one-week horizon being higher than that of the one-month horizon implies that the $R V$ can be explained well by the IV for the one-week horizon; that is, IV forecast of $R V$ for oneweek horizon outperforms its performance for the one-month horizon. The MZ regression analysis uses the OLS (ordinary least squared) method with Newey-West corrected errors for heteroscedasticity and serial correlation.

\subsubsection{Implied Volatility Estimating Options Model Price}

This study calculated the call options and put options model price using the estimated value of IV as the input for the BSM options pricing model. The $C_{t}^{m k t, k}$ and $P_{t}^{m k t, k}$ in Equations (5) and (6) were substituted with call options model price $\left(\hat{\Pi}_{c, t}^{\text {mod,k}}\right)$ and put options model price $\left(\hat{\Pi}_{p, t}^{m o d, k}\right)$ as in Equations (13) and (14), respectively.

$$
\begin{gathered}
\hat{\Pi}_{c, t}^{m o d, k}=S_{t} \xi_{t} N\left[d_{1, t}\left(\hat{\sigma}_{t-i}^{k, l}\right)\right]-X_{t} \eta_{t} N\left[d_{2, t}\left(\hat{\sigma}_{t-i}^{k, l}\right)\right] \\
\hat{\Pi}_{p, t}^{m o d, k}=X_{t} \eta_{t} N\left[-d_{2, t}\left(\hat{\sigma}_{t-i}^{k, l}\right)\right]-S_{t} \xi_{t} N\left[-d_{1, t}\left(\hat{\sigma}_{t-i}^{k, l}\right)\right]
\end{gathered}
$$

\subsubsection{Options Pricing Error Estimation}

The options pricing error (OPE) is the difference between the ATM options market price and the estimated options model price. The OPE is measured using standard statistical 
accuracy criteria, including mean absolute error (MAE), mean squared error (MSE), and the root mean squared error (RMSE), as in Equations (15)-(17), respectively.

$$
\begin{gathered}
M A E_{u}^{m, k, l}=\frac{1}{n} \sum_{t=1}^{n}\left|\Pi_{u, t}^{A T M, k, l}-\hat{\Pi}_{u, t}^{m o d, k, l}\right| \\
M S E_{u}^{m, k, l}=\frac{1}{n} \sum_{t=1}^{n}\left(\Pi_{u, t}^{A T M, k, l}-\hat{\Pi}_{u, t}^{m o d, k, l}\right)^{2} \\
\operatorname{RMSE}_{u}^{m, k, l}=\sqrt{\frac{1}{n} \sum_{t=1}^{n}\left(\Pi_{u, t}^{A T M, k, l}-\hat{\Pi}_{u, t}^{m o d, k, l}\right)^{2}}
\end{gathered}
$$

where $\forall_{u}=$ call price, put price.

\section{Results}

Table 1 describes the performance of IV to forecast $R V$ for the within-week forecast horizon, one-week forecast horizon, and one-month forecast horizon. $\mathrm{R}^{2}$ values from the forecasting regression in Equation (12) are reported. The IV with the highest $\mathrm{R}^{2}$ is preferred.

For the within-week forecast horizon, in the opening of Tuesday, three-month $\left(R^{2}=0.336\right)$ maturity IV outperformed in forecasting the $R V$. In the midday of Wednesday, two-month $\left(\mathrm{R}^{2}=0.335\right)$ maturity IV outperformed in forecasting the $R V$. In the closing period of Monday, two-month $\left(R^{2}=0.379\right)$ maturity IV performed better when predicting the $R V$. Overall findings for the within-week horizon indicated that the two-month maturity IV $\left(R^{2}=0.379\right)$ in the closing period of Monday (begin-week day) were the most superior to the forecast of $R V$.

For the one-week forecast horizon, in the opening period of Tuesday, one-month $\left(\mathrm{R}^{2}=0.465\right)$ maturity IV performed better in forecasting $R V$. Likewise, in the midday period of Tuesday, one-month $\left(R^{2}=0.432\right)$ maturity IV showed better performance when predicting $R V$. Next, in the closing period of Monday, one-month $\left(\mathrm{R}^{2}=0.472\right)$ maturity IV was superior in predicting $R V$. Overall findings for the one-week horizon revealed that one-month maturity IV $\left(R^{2}=0.472\right)$ in the closing period of Monday (begin-week day) held better predictive power when forecasting $R V$.

For the one-month forecast horizon, in the opening period of Tuesday, two-month $\left(\mathrm{R}^{2}=0.386\right)$ maturity IV performed better when forecasting $R V$. In the midday period of Tuesday, two-month $\left(R^{2}=0.332\right)$ maturity IV held higher predictive power when predicting $R V$. Finally, in the closing period of Tuesday, two-month $\left(R^{2}=0.393\right)$ maturity IV was superior when predicting $R V$. Overall findings for the one-month horizon suggested that the two-month maturity IV $\left(R^{2}=0.393\right)$ in the closing periods of Tuesday (begin-week day) held higher forecasting capabilities in predicting $R V$.

The closing period IV better performed in forecasting $R V$ for within-week, one-week, and one-month forecast horizons. Therefore, this study estimated the currency options price using IV based on options traded only during closing periods with a one-month, two-month, and three-month maturity. The closing period IV were used as inputs for the Equations (13) and (14) to estimate the call and put options model price, respectively. The MAE, MSE, and RMSE methods were employed in Equation (15), Equation (16) and Equation (17), respectively, to measure the options pricing error (OPE).

Table 2 describes the performance of IV to price the AUD options for the within-week forecast horizon, one-week forecast horizon, and one-month forecast horizon. 
Table 1. Implied volatility (IV) forecast realised volatility (RV) for Australian dollar (AUD) options for within-week, one-week, and one-month forecast horizon.

\begin{tabular}{|c|c|c|c|c|c|c|c|c|c|c|c|c|c|c|c|}
\hline \multirow{2}{*}{\multicolumn{2}{|c|}{ Time to Maturity }} & \multicolumn{4}{|c|}{ Within-Week Forecast } & \multicolumn{5}{|c|}{ One-Week Forecast } & \multicolumn{5}{|c|}{ One-Month Forecast } \\
\hline & & $\begin{array}{l}\text { Mon to } \\
\text { Fri }\end{array}$ & $\begin{array}{l}\text { Tue to } \\
\text { Fri }\end{array}$ & $\begin{array}{l}\text { Wed to } \\
\text { Fri }\end{array}$ & $\begin{array}{l}\text { Thu to } \\
\text { Fri }\end{array}$ & $\begin{array}{l}\text { Mon to } \\
\text { Mon }\end{array}$ & $\begin{array}{l}\text { Tue to } \\
\text { Tue }\end{array}$ & $\begin{array}{l}\text { Wed to } \\
\text { Wed }\end{array}$ & $\begin{array}{l}\text { Thu to } \\
\text { Thu }\end{array}$ & Fri to Fri & $\begin{array}{l}\text { Mon to } \\
\text { Mon }\end{array}$ & $\begin{array}{l}\text { Tue to } \\
\text { Tue }\end{array}$ & $\begin{array}{l}\text { Wed to } \\
\text { Wed }\end{array}$ & $\begin{array}{l}\text { Thu to } \\
\text { Thu }\end{array}$ & Fri to Fri \\
\hline \multicolumn{16}{|c|}{ Panel A: Opening period (9:30-10:00) } \\
\hline \multirow[b]{2}{*}{ 1-month } & Slope & 0.207 & 0.248 & 0.187 & 0.152 & 0.204 & 0.227 & 0.249 & 0.193 & 0.290 & 0.199 & 0.197 & 0.227 & 0.138 & 0.257 \\
\hline & $R^{2}$ & 0.133 & $0.195^{1}$ & 0.114 & 0.102 & 0.405 & $0.465^{2}$ & 0.307 & 0.262 & 0.305 & 0.227 & $0.228^{1}$ & 0.162 & 0.092 & 0.151 \\
\hline \multirow{2}{*}{ 2-month } & Slope & 0.415 & 0.479 & 0.483 & 0.443 & 0.366 & 0.414 & 0.504 & 0.445 & 0.445 & 0.324 & 0.337 & 0.449 & 0.357 & 0.361 \\
\hline & $\mathrm{R}^{2}$ & 0.294 & 0.228 & $0.335^{2}$ & 0.300 & 0.308 & $0.365^{1}$ & 0.321 & 0.342 & 0.238 & 0.356 & $0.386^{2}$ & 0.263 & 0.217 & 0.177 \\
\hline \multirow{2}{*}{ 3-month } & Slope & 0.554 & 0.548 & 0.569 & 0.508 & 0.472 & 0.435 & 0.495 & 0.482 & 0.540 & 0.409 & 0.454 & 0.447 & 0.285 & 0.439 \\
\hline & $R^{2}$ & 0.221 & $0.336^{2}$ & 0.288 & 0.270 & 0.253 & $0.284^{1}$ & 0.161 & 0.183 & 0.212 & 0.249 & $0.295^{1}$ & 0.162 & 0.202 & 0.170 \\
\hline \multicolumn{16}{|c|}{ Panel B: Midday period (12:30-13:00) } \\
\hline \multirow{2}{*}{ 1-month } & Slope & 0.248 & 0.245 & 0.207 & 0.253 & 0.216 & 0.217 & 0.227 & 0.310 & 0.260 & 0.194 & 0.196 & 0.205 & 0.215 & 0.224 \\
\hline & $\mathrm{R}^{2}$ & 0.198 & $0.214^{2}$ & 0.142 & 0.172 & 0.400 & $0.432^{1}$ & 0.275 & 0.349 & 0.235 & 0.224 & $0.260^{2}$ & 0.156 & 0.159 & 0.141 \\
\hline \multirow{2}{*}{ 2-month } & Slope & 0.427 & 0.411 & 0.390 & 0.425 & 0.364 & 0.353 & 0.397 & 0.436 & 0.390 & 0.304 & 0.317 & 0.364 & 0.347 & 0.290 \\
\hline & $\mathrm{R}^{\frac{1}{2}}$ & 0.246 & $0.280^{1}$ & 0.244 & 0.257 & 0.356 & $0.375^{2}$ & 0.274 & 0.347 & 0.218 & 0.261 & $0.332^{1}$ & 0.241 & 0.232 & 0.135 \\
\hline \multirow{2}{*}{ 3-month } & Slope & 0.470 & 0.486 & 0.465 & 0.479 & 0.396 & 0.419 & 0.473 & 0.513 & 0.479 & 0.332 & 0.385 & 0.413 & 0.415 & 0.362 \\
\hline & $\mathrm{R}^{2}$ & 0.250 & $0.262^{1}$ & 0.219 & 0.240 & 0.299 & $0.317^{2}$ & 0.189 & 0.315 & 0.191 & 0.241 & $0.327^{3}$ & 0.208 & 0.230 & 0.125 \\
\hline \multicolumn{16}{|c|}{ Panel C: Closing period (15:30-16:00) } \\
\hline \multirow{2}{*}{ 1-month } & Slope & 0.274 & 0.247 & 0.224 & 0.272 & 0.244 & 0.221 & 0.260 & 0.287 & 0.301 & 0.228 & 0.181 & 0.200 & 0.207 & 0.247 \\
\hline & $\mathrm{R}^{2}$ & $0.313^{3}$ & 0.207 & 0.160 & 0.213 & $0.472^{3, *}$ & 0.435 & 0.317 & 0.329 & 0.257 & 0.210 & $0.275^{3}$ & 0.146 & 0.158 & 0.144 \\
\hline \multirow[b]{2}{*}{ 2-month } & Slope & 0.432 & 0.427 & 0.426 & 0.458 & 0.378 & 0.380 & 0.423 & 0.430 & 0.434 & 0.320 & 0.322 & 0.353 & 0.350 & 0.325 \\
\hline & $R^{2}$ & $0.379^{3, *}$ & 0.273 & 0.252 & 0.294 & $0.396^{3}$ & 0.379 & 0.298 & 0.353 & 0.251 & 0.285 & $0.393^{3, *}$ & 0.215 & 0.248 & 0.158 \\
\hline \multirow{2}{*}{ 3-month } & Slope & 0.513 & 0.500 & 0.489 & 0.501 & 0.438 & 0.438 & 0.517 & 0.496 & 0.512 & 0.370 & 0.394 & 0.426 & 0.420 & 0.399 \\
\hline & $\mathrm{R}^{2}$ & $0.352^{3}$ & 0.258 & 0.248 & 0.292 & $0.335^{3}$ & 0.310 & 0.240 & 0.290 & 0.228 & 0.284 & $0.310^{2}$ & 0.207 & 0.238 & 0.146 \\
\hline
\end{tabular}

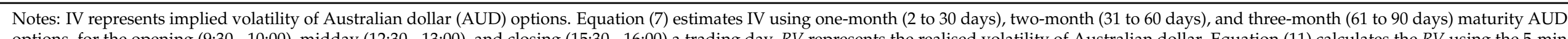

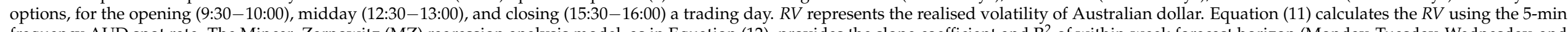

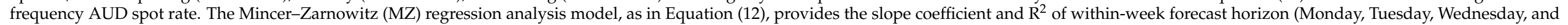

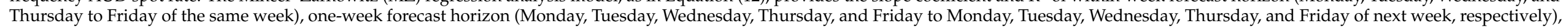

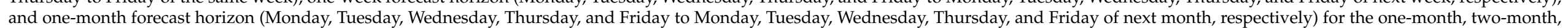

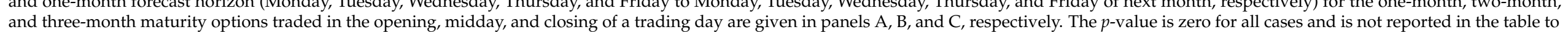

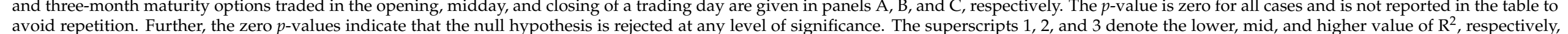

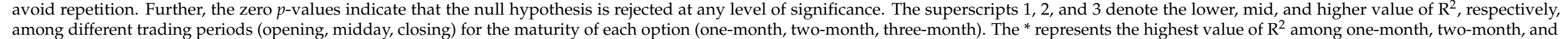

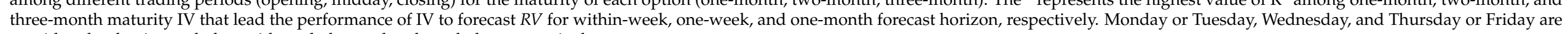
considered as begin-week day, mid-week day, and end-week day, respectively. 
Table 2. Estimate options pricing error for AUD options for the within-week, one-week, and one-month horizon.

\begin{tabular}{|c|c|c|c|c|c|c|c|c|c|c|c|c|c|c|c|}
\hline \multirow{2}{*}{\multicolumn{2}{|c|}{ Time to Maturity }} & \multicolumn{4}{|c|}{ Within-Week Forecast } & \multicolumn{5}{|c|}{ One-Week Forecast } & \multicolumn{5}{|c|}{ One-Month Forecast } \\
\hline & & $\begin{array}{l}\text { Mon to } \\
\text { Fri }\end{array}$ & $\begin{array}{l}\text { Tue to } \\
\text { Fri }\end{array}$ & $\begin{array}{l}\text { Wed to } \\
\text { Fri }\end{array}$ & $\begin{array}{l}\text { Thu to } \\
\text { Fri }\end{array}$ & $\begin{array}{l}\text { Mon to } \\
\text { Mon }\end{array}$ & $\begin{array}{l}\text { Tue to } \\
\text { Tue }\end{array}$ & $\begin{array}{l}\text { Wed to } \\
\text { Wed }\end{array}$ & $\begin{array}{l}\text { Thu to } \\
\text { Thu }\end{array}$ & Fri to Fri & $\begin{array}{l}\text { Mon to } \\
\text { Mon }\end{array}$ & $\begin{array}{l}\text { Tue to } \\
\text { Tue }\end{array}$ & $\begin{array}{l}\text { Wed to } \\
\text { Wed }\end{array}$ & $\begin{array}{l}\text { Thu to } \\
\text { Thu }\end{array}$ & Fri to Fri \\
\hline \multicolumn{16}{|c|}{ Panel A: OPE under MAE measure } \\
\hline \multirow[b]{2}{*}{ 1-month } & CALL & $0.137^{3}$ & 0.143 & 0.154 & 0.155 & $0.142^{3}$ & 0.151 & 0.187 & 0.156 & 0.146 & 0.158 & $0.146^{2}$ & 0.185 & 0.160 & 0.165 \\
\hline & PUT & $0.067^{3}$ & 0.082 & 0.073 & 0.077 & $0.056^{3}$ & 0.064 & 0.075 & 0.076 & 0.069 & 0.091 & $0.086^{2}$ & 0.102 & 0.091 & 0.091 \\
\hline \multirow{2}{*}{ 2-month } & CALL & $0.138^{2}$ & 0.140 & 0.140 & 0.145 & $0.149^{2}$ & 0.154 & 0.204 & 0.158 & 0.155 & 0.151 & $0.144^{3}$ & 0.180 & 0.154 & 0.154 \\
\hline & PUT & $0.068^{2}$ & 0.072 & 0.077 & 0.071 & $0.061^{2}$ & 0.071 & 0.082 & 0.083 & 0.075 & 0.077 & $0.077^{3}$ & 0.097 & 0.087 & 0.078 \\
\hline 3-month & PUT & $0.074^{1}$ & 0.075 & 0.078 & 0.077 & $0.079^{1}$ & 0.082 & 0.091 & 0.090 & 0.081 & 0.098 & $0.094^{1}$ & 0.111 & 0.106 & 0.098 \\
\hline \multicolumn{16}{|c|}{ Panel B: OPE under MSE measure } \\
\hline \multirow{2}{*}{ 1-month } & CALL & $0.036^{3}$ & 0.048 & 0.055 & 0.044 & $0.044^{3}$ & 0.049 & 0.079 & 0.050 & 0.046 & 0.050 & $0.050^{1}$ & 0.097 & 0.064 & 0.061 \\
\hline & PUT & $0.009^{3}$ & 0.040 & 0.011 & 0.032 & $0.007^{3}$ & 0.009 & 0.015 & 0.013 & 0.010 & 0.028 & $0.020^{1}$ & 0.040 & 0.021 & 0.020 \\
\hline \multirow[b]{2}{*}{ 2-month } & CALL & $0.038^{2}$ & 0.041 & 0.037 & 0.041 & $0.050^{1}$ & 0.064 & 0.096 & 0.054 & 0.054 & 0.045 & $0.043^{3}$ & 0.077 & 0.048 & 0.050 \\
\hline & PUT & $0.010^{2}$ & 0.011 & 0.013 & 0.010 & $0.008^{2}$ & 0.011 & 0.015 & 0.039 & 0.039 & 0.018 & $0.012^{3}$ & 0.024 & 0.018 & 0.013 \\
\hline \multirow{2}{*}{ 3-month } & CALL & $0.039^{1}$ & 0.050 & 0.049 & 0.045 & $0.045^{2}$ & 0.054 & 0.092 & 0.054 & 0.049 & 0.046 & $0.043^{2}$ & 0.087 & 0.051 & 0.062 \\
\hline & PUT & $0.012^{1}$ & 0.021 & 0.021 & 0.023 & $0.017^{1}$ & 0.023 & 0.026 & 0.018 & 0.024 & 0.022 & $0.017^{2}$ & 0.027 & 0.026 & 0.020 \\
\hline \multirow{2}{*}{ 1-month } & CALL & $0.190^{3}$ & 0.219 & 0.236 & 0.210 & $0.210^{3}$ & 0.222 & 0.282 & 0.224 & 0.222 & 0.225 & $0.223^{1}$ & 0.312 & 0.254 & 0.247 \\
\hline & PUT & $0.095^{3}$ & 0.201 & 0.106 & 0.180 & $0.085^{3}$ & 0.098 & 0.125 & 0.115 & 0.098 & 0.169 & $0.141^{1}$ & 0.200 & 0.145 & 0.142 \\
\hline \multirow{2}{*}{ 2-month } & CALL & $0.195^{2}$ & 0.204 & 0.192 & 0.203 & $0.213^{2}$ & 0.254 & 0.310 & 0.233 & 0.254 & 0.212 & $0.207^{3}$ & 0.278 & 0.219 & 0.224 \\
\hline & PUT & $0.104^{2}$ & 0.106 & 0.114 & 0.102 & $0.091^{2}$ & 0.106 & 0.125 & 0.197 & 0.106 & 0.134 & $0.113^{3}$ & 0.155 & 0.136 & 0.114 \\
\hline \multirow{2}{*}{ 3-month } & CALL & $0.197^{1}$ & 0.224 & 0.297 & 0.213 & $0.224^{1}$ & 0.233 & 0.304 & 0.233 & 0.233 & 0.215 & $0.208^{2}$ & 0.296 & 0.226 & 0.249 \\
\hline & PUT & $0.110^{1}$ & 0.207 & 0.209 & 0.214 & $0.117^{1}$ & 0.127 & 0.129 & 0.135 & 0.120 & 0.148 & $0.130^{2}$ & 0.167 & 0.162 & 0.143 \\
\hline
\end{tabular}

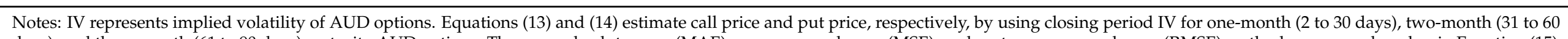

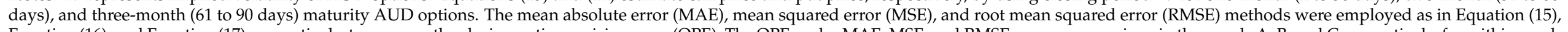

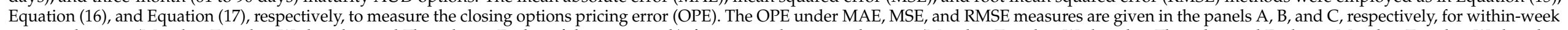

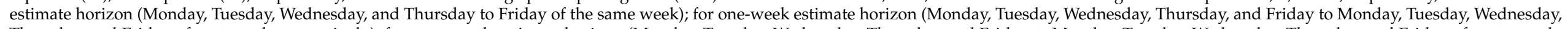

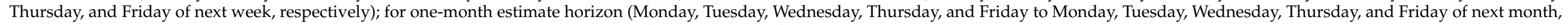

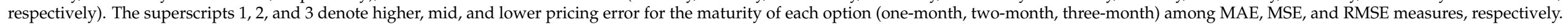
Monday or Tuesday, Wednesday, and Thursday or Friday are considered as begin-week day, mid-week day, and end-week day, respectively. 
For the within-week forecast horizon, under the MAE measure, one-month (call pricing error $=0.137$ and put pricing error $=0.067$ ) maturity IV of Monday outperformed when estimating AUD call and put options. Next, for the MSE measure, one-month (call pricing error $=0.036$ and put pricing error $=0.009$ ) maturity IV of Monday was superior to price AUD call and put options. Finally, under the RMSE measure of Monday, one-month (call pricing error $=0.190$ and put pricing error $=0.095$ ) maturity IV held appropriate information to compute AUD call and put options. Overall, the one-month maturity of Monday (begin-week day) IV contained vital information to price AUD options.

For the one-week horizon, under the MAE measure, one-month (call pricing error = 0.142 and put pricing error $=0.056$ ) maturity IV of Monday held appropriate information to estimate the AUD call and put options. Next, for the MSE measure, one-month (call pricing error $=0.044$ and put pricing error $=0.007$ ) maturity IV of Monday was superior to price the AUD call and put options. Finally, under the RMSE measure, one-month (call pricing error $=0.210$ and put pricing error $=0.085$ ) maturity IV of Monday contained vital information to compute the AUD call and put options. Overall, the one-month maturity of Monday (begin-week day) IV held critical information to estimate the price of the AUD options.

For the one-month horizon, under the MAE measure, two-month (call pricing error $=0.144$ and put pricing error $=0.077$ ) maturity IV of Tuesday provided appropriate information to estimate the AUD call and put options. Next, for the MSE measure, twomonth (call pricing error $=0.043$ and put pricing error $=0.012$ ) maturity IV of Tuesday outperformed when pricing AUD call and put options. Finally, under the RMSE measure, two-month (call pricing error $=0.207$ and put pricing error $=0.113$ ) maturity IV of Tuesday contained vital information to compute the AUD call and put options. Overall, two-month maturity of Tuesday (begin-week day) IV held critical information to estimate the price of the AUD options.

\section{Discussion}

Our paper employed the tick data obtained from Thomson Reuters' database, an archive of historical every-minute data drawn from the real-time content. The use of big data would enable efficiency and speed to innovation. Financial innovation, such as venture capital, equity funds, and exchange-traded funds contributed positively to the financial deepening and economic growth [61,62]. The application of the information in portfolio management also allows the generation of high-frequency trading, which is considered a financial innovation, concentrating on order flow and rapidly evolving information [63]. In the derivatives market, millions of calculations need to be conducted daily to price derivative instruments to manage the risks and to determine hedge positions. However, information obtained from these computations is useful for only a limited period and will be outdated when the market moves. De Spiegeleer et al. [64] indicated that the use of real-time data and market information was mandatory in successfully running a derivative business in the present era of information explosion. As technology is increasing and the world overwhelmed by numbers and digits [65], forecasting volatility and options price based on the intraday data is crucial for the immediate investment decision making.

The empirical analysis indicated that the IV at the closing period performed better in predicting $R V$ for all forecast horizons. As more intensive trading occurred at the end of the trading day, more valuable information to forecast future volatility can be extracted from the options price at the market close [66]. The within-week horizon provides a mixed picture for IV in terms of holding information to forecast $R V$. It suggests that the IV does not contain relevant information to predict the volatility of the underlying currency of options for a one- to four-day forecast horizon. Therefore, the intraday IV is not appropriate to estimate the currency options price for the within-week horizon. The one-month and two-month maturity; begin-week day and closing period of IV hold relevant information to forecast $R V$ for the one-week and one-month forecast horizon, respectively. It reveals that the information content embedded in one-month and two-month maturity IV is significant in predicting the volatility of the underlying currency of options for the one-week and 
one-month forecast horizon, respectively. Consequently, a one-month and two-month maturity IV is appropriate to estimate the currency options price for the one-week and onemonth estimate horizon, respectively. These findings are in line with the research of Garvey and Gallagher [10] that examined the forecastability of IV using a sample of 16 FTSE-100 stocks and found that IV provided a useful volatility forecasting method, especially for the medium forecasting horizons between ten and thirty days. Although most of the previous research using data from stock market showed that the optimal forecast horizon of IV was from one day to less than thirty days [22,56], our results showed that the IV did not work well for the short forecast horizons from one day to four days, but it performed superiorly for the medium forecast horizons from one week to one month.

\section{Conclusions}

The accuracy of currency options pricing plays a crucial role in managing financial risk, providing a source of financial leverage for speculators, and preventing the opportunity for abnormal arbitrage profit. To calculate prices of currency options using the Merton [15] version of the BSM model, only the volatility of the underlying currency is not observable in the market. As volatility estimation errors lead to options mispricing, accurate forecasts of future volatility of underlying assets are essential for estimating and forecasting the currency options price. The IV is widely used to estimate the volatility of FX. The majority of the studies involving IV often find that the most relevant information for predicting an underlying asset's volatility can be found in the options price. Therefore, this paper was particularly interested in FX volatility prediction for pricing currency options. However, it is argued that the daily IV holds discrete information regarding the FX movement at a specific time of the trading day, which is not sufficient for estimating options prices accurately [67]. This study, therefore, introduces intraday IV through estimating IV for the price of options with different maturity during the opening, midday, and closing period of a trading day. The intraday IV approach will add a new dimension in the literature for the pricing currency option with higher accuracy.

Overall, the results suggest four key insights. First, three-month maturity IV does not hold vital information about future volatility of the underlying currency and pricing currency options. It happens because the shorter period information of one-month and two-month maturity options are useful compared to the longer period information of three-month maturity options. Second, IV incorporating all information is not relevant in computing the value of currency options for a horizon estimate that is less than a week. This is due to FX volatility following clustering, and both information content day (e.g., Monday) and forecasting day (i.e., Friday) lying in the same cluster. Third, IV for the closing period on Monday or Tuesday includes the most useful information compared to other periods of trading day and other days of the week when forecasting the volatility of the underlying currency and estimating the price of currency options. This occurs as all weekdays do not hold equally relevant information or critical information diminishes gradually from the middle of the week. Fourth, the shorter (longer) maturity IV provides essential information when pricing currency options for the shorter (longer) horizon. If the currency options are overpriced, the hedgers and speculators experience the higher cost for buying or holding currency options. However, the options become profitable for the options seller or writer. Further, the cost of hedging and speculation is less when options are underpriced. This also makes an opportunity cost loss for the options seller. The paper's results can provide valuable information to fund managers to hedge extreme risk and allow policy makers to construct a comprehensive strategy to prevent the opportunity for abnormal arbitrage profit. High-frequency traders can refer to these results to select valuable and useful intraday information for their immediate decision marking. The sample data obtained for this research from the exchange-traded market is not as big as the OTC market. BIS (2019) reported that the currency options are traded not only in the exchanges, but a considerable volume of currency options are also traded in the interbank market due to the customisation benefit of OTC currency options 
over options traded in exchanges. Moreover, the study limits the data sample in the AUD currency options that represent the developed market. The research findings may not be appropriate to apply to the other FX markets that experience different characteristics such as currency markets of emerging countries. The covered period of the dataset is from 1 January 2010 to 31 December 2017 due to the large volume of high-frequency data that needs to be collected. Therefore, our research captures particular economic circumstances in the context of the post Global Financial crisis period. The research results may be not suitable to apply for different economic circumstances such as before and during the crisis period. However, the information content of the IV during a crisis period is also peculiarly relevant $[68,69]$ as it provides incremental and valuable information to hedge financial risk and to bring us a better understanding of market sentiment and behaviour. Hence, the avenue for potential further research concerns extending this research to the emerging currency options, using data from the OTC market, or testing the research results in different economic circumstances. As each type and each period of FX market contains peculiar characteristics, the investigations of intraday IV in other market conditions are necessary to provide a fully comprehensive view of its performance in forecasting the volatility of the underlying currency and estimating the value of currency options.

Author Contributions: Conceptualization, T.L. and A.H.; methodology, T.L. and A.H.; software, T.L. and A.H.; validation, T.L., A.H., and K.H.; formal analysis, T.L.; investigation, T.L.; resources, T.L. and A.H.; data curation, T.L. and A.H.; writing—original draft preparation, T.L., A.H., and K.H.; writing-review and editing, T.L., A.H., and K.H.; visualization, T.L.; supervision, A.H. and K.H.; project administration, A.H.; funding acquisition, A.H. All authors have read and agreed to the published version of the manuscript.

Funding: This research received no external funding.

Data Availability Statement: Data is available on request.

Conflicts of Interest: For this study, the authors declare no conflict of interest.

\section{References}

1. Reserve Bank of Australia. Available online: https://www.rba.gov.au/media-releases/2019/mr-19-25-tables.html (accessed on 9 December 2020).

2. Vohra, S.; Fabozzi, F.J. Effectiveness of developed and emerging market FX options in active currency risk management. J. Int. Money Financ. 2019, 96, 130-146. [CrossRef]

3. Beer, S.; Fink, H. Dynamics of foreign exchange implied volatility and implied correlation surfaces. Quant. Financ. 2019, 19, 1293-1320. [CrossRef]

4. Lai, Y.-W.; Lin, C.-F.; Tang, M.-L. Mispricing and trader positions in the S\&P 500 index futures market. N. Am. J. Econ. Financ. 2017, 42, 250-265. [CrossRef]

5. Becker, R.; Clements, A.E.; White, S.I. On the informational efficiency of S\&P500 implied volatility. N. Am. J. Econ. Financ. 2006, 17, 139-153. [CrossRef]

6. Black, F.; Scholes, M. The Pricing of Options and Corporate Liabilities. World Sci. Ref. Conting. Claims Anal. Corp. Financ. 2019, 83, 3-21. [CrossRef]

7. Yang, S.-H.; Lee, J. Predicting a distribution of implied volatilities for option pricing. Expert Syst. Appl. 2011, 38, 1702-1708. [CrossRef]

8. Fleming, J. The quality of market volatility forecasts implied by S\&P 100 index option prices. J. Empir. Financ. 1998, 5, 317-345. [CrossRef]

9. Nelson, D.B. Conditional Heteroskedasticity in Asset Returns: A New Approach. Econometrica 1991, 59, 347. [CrossRef]

10. Garvey, J.; Gallagher, L.A. The Realised-Implied Volatility Relationship: Recent Empirical Evidence from FTSE-100 Stocks. J. Forecast. 2011, 31, 639-660. [CrossRef]

11. Kearney, F.; Cummins, M.; Murphy, F. Forecasting implied volatility in foreign exchange markets: A functional time series approach. Eur. J. Financ. 2017, 24, 1-18. [CrossRef]

12. Muzzioli, S. Option-based forecasts of volatility: An empirical study in the DAX-index options market. Eur. J. Financ. 2010, 16, 561-586. [CrossRef]

13. Taylor, S.J.; Yadav, P.K.; Zhang, Y. The information content of implied volatilities and model-free volatility expectations: Evidence from options written on individual stocks. J. Bank. Financ. 2010, 34, 871-881. [CrossRef]

14. Corredor, P.; Santamaria, R. Forecasting volatility in the Spanish option market. Appl. Financ. Econ. 2004, 14, 1-11. [CrossRef]

15. Merton, R.C. Theory of Rational Option Pricing. Bell J. Econ. Manag. Sci. 1973, 4, 141. [CrossRef]

16. Cruz, M.G. Modeling, Measuring and Hedging Operational Risk, 1st ed.; John Wiley \& Sons Ltd.: New York, NY, USA, 2008 ; pp. 1-346.

17. Singh, S. Performance of Black-Scholes model with TSRV estimates. Manag. Financ. 2015, 41, 857-870. [CrossRef] 
18. Tu, A.H.; Hsieh, W.-L.G.; Wu, W.-S. Market uncertainty, expected volatility and the mispricing of S\&P 500 index futures. J. Empir. Financ. 2016, 35, 78-98. [CrossRef]

19. Byun, S.J.; Hyun, J.; Sung, W.J. Estimation of stochastic volatility and option prices. J. Futur. Mark. 2020, 1-12. [CrossRef]

20. Wang, Y.-H.; Wang, Y.-Y. The Information Content of Intraday Implied Volatility for Volatility Forecasting. J. Forecast. 2015, 35, 167-178. [CrossRef]

21. Beckers, S. Standard deviations implied in option prices as predictors of future stock price variability. J. Bank. Financ. 1981, 5, 363-381. [CrossRef]

22. Brous, P.; Ince, U.; Popova, I. Volatility forecasting and liquidity: Evidence from individual stocks. J. Deriv. Hedge Funds 2010, 16, 144-159. [CrossRef]

23. Busch, T.; Christensen, B.J.; Nielsen, M.Ø. The role of implied volatility in forecasting future realized volatility and jumps in foreign exchange, stock, and bond markets. J. Econ. 2011, 160, 48-57. [CrossRef]

24. Latane, H.A.; Rendleman, R.J. Standard Deviations of Stock Price Ratios Implied in Option Prices. J. Financ. 1976, 31, 369. [CrossRef]

25. Schmalensee, R.; Trippi, R.R. Common stock volatility expectations implied by option premia. J. Financ. 1978, 33, 129-147. [CrossRef]

26. Andersen, T.G.; Bollerslev, T.; Diebold, F.X.; Labys, P. Exchange Rate Returns Standardised by Realised Volatility Are (Nearly) Gaussian. Multinatl. Financ. J. 2000, 4, 159-179. [CrossRef]

27. Scott, E.; Tucker, A.L. Predicting currency return volatility. J. Bank. Financ. 1989, 13, 839-851. [CrossRef]

28. Goodhart, C.A.; O’Hara, M. High frequency data in financial markets: Issues and applications. J. Empir. Financ. 1997, 4, 73-114. [CrossRef]

29. Cai, C.X.; Hudson, R.; Keasey, K. Intra Day Bid-Ask Spreads, Trading Volume and Volatility: Recent Empirical Evidence from the London Stock Exchange. J. Bus. Financ. Account. 2004, 31, 647-676. [CrossRef]

30. Bank for International Settlements. Available online: https://www.bis.org/publ/bppdf/bispap109.pdf (accessed on 9 December 2020).

31. Xu, X.; Taylor, S.J. The Term Structure of Volatility Implied by Foreign Exchange Options. J. Financ. Quant. Anal. 1994, 29, 57. [CrossRef]

32. Jorion, P. Predicting Volatility in the Foreign Exchange Market. J. Financ. 1995, 50, 507-528. [CrossRef]

33. Kazantzis, C.; Tessaromatis, N. Volatility in currency markets. Manag. Financ. 2001, 27, 1-22. [CrossRef]

34. Kim, M.; Kim, M. Implied volatility dynamics in the foreign exchange markets. J. Int. Money Financ. 2003, 22, 511-528. [CrossRef]

35. Chang, E.J.; Tabak, B.M. Are implied volatilities more informative? The Brazilian real exchange rate case. Appl. Financ. Econ. 2007, 17, 569-576. [CrossRef]

36. P1lbeam, K.; Langeland, K.N. Forecasting exchange rate volatility: GARCH models versus implied volatility forecasts. Int. Econ. Econ. Policy 2014, 12, 127-142. [CrossRef]

37. Sahoo, S.; Trivedi, P. The Interrelationship Between Implied and Realized Exchange Rate Volatility in India †. IUP J. Appl. Econ. 2018, 17, 7-26.

38. Wong, A.H.-S.; Heaney, R. Volatility Smile and One-Month Foreign Currency Volatility Forecasts. J. Future Mark. 2016, 37, $286-312$. [CrossRef]

39. Covrig, V.; Low, B.S. The quality of volatility traded on the over-the-counter currency market: A multiple horizons study. J. Future Mark. 2003, 23, 261-285. [CrossRef]

40. Pong, S.; Shackleton, M.B.; Taylor, S.J.; Xu, X. Forecasting currency volatility: A comparison of implied volatilities and AR(FI)MA models. J. Bank. Financ. 2004, 28, 2541-2563. [CrossRef]

41. Christoffersen, P.; Mazzotta, S. The Accuracy of Density Forecasts from Foreign Exchange Options. J. Financ. Econ. 2005, 3, 578-605. [CrossRef]

42. Engle, R.F. The Econometrics of Ultra-high-frequency Data. Econometrica 2000, 68, 1-22. [CrossRef]

43. Batten, J.A.; Lucey, B.; McGroarty, F.; Peat, M.; Urquhart, A. Stylized facts of intraday precious metals. PLoS ONE 2017, 12, e0174232. [CrossRef] [PubMed]

44. Wood, R.A.; McInish, T.H.; Ord, J.K. An Investigation of Transactions Data for NYSE Stocks. J. Financ. 1985, 40, 723-739. [CrossRef]

45. Gerety, M.S.; Mulherin, J.H. Trading Halts and Market Activity: An Analysis of Volume at the Open and the Close. J. Financ. 1992, 47, 1765-1784. [CrossRef]

46. Brock, W.A.; Kleidon, A.W. Periodic market closure and trading volume. J. Econ. Dyn. Control. 1992, 16, 451-489. [CrossRef]

47. McInish, T.H.; Wood, R.A. An analysis of transactions data for the Toronto Stock Exchange. J. Bank. Financ. 1990, 14, 441-458. [CrossRef]

48. Hamao, Y.; Hasbrouck, J. Securities Trading in the Absence of Dealers: Trades and Quotes on the Tokyo Stock Exchange. Rev. Financ. Stud. 1995, 8, 849-878. [CrossRef]

49. Ellul, A.; Shin, H.S.; Tonks, I. Towards Deep and Liquid Markets: Lessons from Open and Close at the London Stock Exchange; LSE Financial Markets Group Working Paper: London, UK, 2002.

50. Naik, N.Y.; Yadav, P.K. The Effects of Market Reform on Trading Costs of Public Investors: Evidence from the London Stock Exchange. Ssrn Electron. J. 1999. [CrossRef]

51. Taylor, S.J.; Xu, X. The incremental volatility information in one million foreign exchange quotations. J. Empir. Financ. 1997, 4, 317-340. [CrossRef]

52. Barndorff-Nielsen, O.E.; Shephard, N. Econometric Analysis of Realised Volatility and Its Use in Estimating Stochastic Volatility Models. Journal of the Royal Statistical Society. J. R. Stat. Soc. Ser. B Stat. Methodol. 2002, 64, 253-280. [CrossRef] 
53. Liu, L.Y.; Patton, A.J.; Sheppard, K. Does anything beat 5-minute RV? A comparison of realized measures across multiple asset classes. J. Econ. 2015, 187, 293-311. [CrossRef]

54. Hull, J.; White, A. The Pricing of Options on Assets with Stochastic Volatilities. J. Financ. 1987, 42, 281-300. [CrossRef]

55. Xing, Y.; Zhang, X.; Zhao, R. What Does the Individual Option Volatility Smirk Tell Us About Future Equity Returns? J. Financ. Quant. Anal. 2010, 45, 641-662. [CrossRef]

56. Blair, B.J.; Poon, S.-H.; Taylor, S.J. Forecasting S\&P 100 volatility: The incremental information content of implied volatilities and high-frequency index returns. J. Econ. 2001, 105, 5-26. [CrossRef]

57. Press, W.H.; Flannery, B.P.; Vetterling, W.T. Numerical Recipes in C: The Art of Scientific Computing, 2nd ed.; Cambridge University Press: Cambridge, UK, 1992; ISBN 0-521-43108-5.

58. Andersen, T.G.; Bollerslev, T. Answering the Skeptics: Yes, Standard Volatility Models do Provide Accurate Forecasts. Int. Econ. Rev. 1998, 39, 885. [CrossRef]

59. Mincer, J.; Zarnowitz, V. The evaluation of economic forecasts. In Economic Forecasts and Expectations; Zarnowitz, J., Ed.; National Bureau of Economic Research: New York, NY, USA, 1969; pp. 3-46.

60. Guler, K.; Ng, P.T.; Xiao, Z. Mincer-Zarnowitz quantile and expectile regressions for forecast evaluations under aysmmetric loss functions. J. Forecast. 2017, 36, 651-679. [CrossRef]

61. Lerner, J.; Tufano, P. The Consequences of Financial Innovation: A Counterfactual Research Agenda. Annu. Rev. Financ. Econ. 2011, 3, 41-85. [CrossRef]

62. Beck, T.; Chen, T.; Lin, C.; Song, F. Financial innovation: The bright and the dark sides. J. Bank. Financ. 2016, 72, 28-51. [CrossRef]

63. Dalko, V.; Wang, M.H. High-frequency trading: Order-based innovation or manipulation? J. Bank. Regul. 2020, 21, 289-298. [CrossRef]

64. De Spiegeleer, J.; Madan, D.B.; Reyners, S.; Schoutens, W. Machine learning for quantitative finance: Fast derivative pricing, hedging and fitting. Quant. Financ. 2018, 18, 1635-1643. [CrossRef]

65. Ye, M.; Li, G. Internet big data and capital markets: A literature review. Financ. Innov. 2017, 3, 6. [CrossRef]

66. Caporale, G.M.; Gil-Alana, L.; Plastun, A.; Makarenko, I. Intraday Anomalies and Market Efficiency: A Trading Robot Analysis. Comput. Econ. 2015, 47, 275-295. [CrossRef]

67. Baillie, R.T.; Bollerslev, T. Intra-Day and Inter-Market Volatility in Foreign Exchange Rates. Rev. Econ. Stud. 1991, 58, 565-585. [CrossRef]

68. Bates, D.S. U.S. stock market crash risk, 1926-2010. J. Financ. Econ. 2012, 105, 229-259. [CrossRef]

69. Hilal, S.; Poon, S.-H.; Tawn, J.A. Hedging the black swan: Conditional heteroskedasticity and tail dependence in S\&P500 and VIX. J. Bank. Financ. 2011, 35, 2374-2387. [CrossRef] 